\title{
Analysis of Group Based Loan Default in Kenya: The Case of Agricultural Finance Corporation of Kenya.
}

\author{
Eunice Andeyo Amwayi ${ }^{1 *}$, Francis Ikapel Omete ${ }^{2}$ \\ Francis Mukatia Asakania ${ }^{3}$ \\ 1Department of Commerce and Economic Studies, Jomo Kenyatta University of Agriculture and Technology \\ P.O.Box 3347-30200 Kitale, Kenya \\ 2 Department of Business Management, University of Eldoret, P.O.Box 1125 Eldoret, Kenya \\ 3 Department of Management Technology and Economics, Garissa University College, P.O Box 1801 Garissa, \\ Kenya
}

\begin{abstract}
The study aimed at investigating group loan default at Agricultural Finance Corporation (AFC), a state owned Development Finance Institution in Kenya formed in 1963, whose main role is to assist in the development of agriculture and agricultural industries by making loans to individual farmers, groups, private companies, public bodies, local authorities and other persons engaging in agricultural activities. AFC began lending to groups in 2006 with its Eldoret Branch of Uasin Gishu County being its pioneer branch. The performance of the group loans was good with a default rate of $0.5 \%$. However, in the succeeding years the performance of the group loans in the Eldoret branch became very erratic recording a high of $80 \%$ default rate in 2008. The findings of the study done in 2013 suggest that amount of loan has no effect on default; size of the group has a significant positive effect on group loan default, while age of the group, experience in borrowing and education level all produced significant negative effect on group loan default. The findings of the study are useful in designing of credit scoring systems by AFC and other lending institutions following the group lending model
\end{abstract}

Key Words: Micro credit, Group lending, Loan default, Grameen, Agricultural Finance Corporation.

\subsection{Background}

\section{Introduction}

The Inter-American Development Bank (1997) reported that micro enterprise makes a major contribution to aggregate employment, production, and national income in Latin America and the Caribbean. Budiantoro (2004) found that 30 percent of GDP in Indonesia was contributed by MEs. MEs provide income and employment for significant workers in the rural and urban areas by producing basic goods and services such as traditional foods, craft, barber and hair salon and hawkers for the needs of rapidly growing populations.

The most challenges faced by MEs around the world are lack of access to credit (Cotler \& Woodruff, 2008; Mel et al., 2007; Tambunan, 2007; Schoombee, 2000; Kurwijila \& Due, 1991). Schoombee (2000) finds that lack of access to formal bank credit is one of the important problems faced by South African micro entrepreneurs in the informal sector. Mel et al. (2007) confirm that missing credit markets is the main limitation for small businesses to grow.

Lending is risky to a micro enterprise because repayment of loans can seldom be fully guaranteed. The failure of a large number of state-sponsored agricultural development banks in many developing countries was due, among other things, to their inability to ensure good repayment rates among their borrowers(Adams et al., 1984; Yaron, 1994). Indeed, throughout Asia, Africa, and Latin America, the last decade has witnessed substantial efforts that aim at opening the poor's access to credit and at the same time improve their incentives to meet repayment obligations. One distinguishing feature of these efforts has been the formation of borrower groups and the use of group responsibility and peer monitoring as the core principles guiding financial transactions. The low income groups are usually excluded from credit facilities because of many reasons. These include insufficient collateral to support their loans, high transaction costs, unstable income, lower literacy and high monitoring costs.

Since the founding of the Grameen Bank in 1976 and following its success in rural Bangladesh, the group lending model has been adopted in over 40 low-income countries ( Pitt and Khandker, 1998). The Agricultural Finance Corporation which is a state owned Development Financial institution in Kenya started offering group credit to small farmers in Uasin Gishu county in 2006 and by the beginning of 2007, the program had expanded more than twofold to include 96 farmer groups which received loans in excess of Kshs. 50million the beneficiaries being approximately 1,440 farmers. Currently, AFC Eldoret has financed 102 groups a total of over Kshs. 64 million. AFC requires the groups to sign a joint liability clause, which means that the group 
members are responsible for repayment of not just their own loans, but also loans taken by all members in their group. The primary purpose of AFC group loans is to enable those who do not own land which used as collateral to access loans. The target groups are mainly women and the youth. However the erratic performance of group loans in AFC calls for a research on the causes of the increasing default rate in group loans schemes. Other main stream privately owned financial institutions and banks have also adopted group loans model.

\subsection{Research problem}

Loan default is one of the critical issues of Micro finance institutions (MFIs) that concerns all stakeholders (Sharma \& Zeller, 1997; Marr, 2002; Maata, 2004; Godquin, 2004) where the high loan default rate is the primary cause of the failure of MFIs (Yaron, 1994; Woolcock, 1999; Marr, 2002; Maata, 2004). High levels of default have caused increased amounts of non- performing loans in the books of many financial institutions. AFC has of recent experienced erratic loan repayment patterns of its group based loan product. Now, whether default is random and influenced by erratic behavior or whether it is influenced by certain factors in a specific situation, group composition and characteristics, needs an empirical investigation. The findings can be used by micro financing institutions to manipulate their credit programs for the better. This research is expected to determine whether age of the group, size of loan, size of group and number of years in formal education has significant influence on repayment of group based loans. The institutions can also be able to develop policy frameworks to sweeten the group loans product.

\subsection{Objectives \\ 1.3.1 General objective}

The research aimed at determining the causes of group loan default in Kenya with specific emphasis on group lending.

\subsubsection{Specific objective}

i) To determine the effect of age of group on loan repayment patterns

ii) To determine the effect of loan size on group loan repayment patterns

iii) To establish effect of education level of group members on group loan repayment

iv) To establish effect of experience in loan taking on loan repayment by groups

v) To establish effect of group size on group loan repayment

\subsection{Hypotheses}

1. $\mathbf{H}_{\mathbf{0}}$ : The age of a group has no significant effects on loan repayment

$\mathbf{H}_{\mathbf{a}}$ : The age of a group has significant effects loan repayment

2. $\mathbf{H}_{\mathbf{0}}$ : The size of loan has no significant effects on loan repayment

$\mathbf{H}_{\mathbf{a}}$ : The size of the loan has significant effects on loan repayment.

3. $\mathbf{H}_{\mathbf{0}}$ : The number of years in formal education for group members has no significant effects on group loan repayment.

$\mathbf{H}_{\mathbf{a}}$ : The number of years in formal education for group members has significant effects on loan repayment.

4. $\mathbf{H}_{\mathbf{o}}$ Experience in loan taking has no significant effects on loan repayment.

$\mathbf{H}_{\mathbf{a}}$ : Experience in loan taking has significant effects on loan repayment.

5. $\mathbf{H}_{\mathbf{0}}$ : The size of the group has no significant effects on loan repayment.

$\mathbf{H}_{\mathbf{a}}$ : The size of the group has significant effects on loan repayment.

\subsection{Microfinance}

\section{Literature Review}

Microfinance refers to the provision of financial services to low-income clients, including consumers and the self- employed, who traditionally lack access to banking and related services (Gonzalez-Vega, 2008). Microfinance is a place for the poor and near poor clients to get access to a high quality financial service, which include not just credit but also savings, insurance and fund transfer. According to Ledgerwood (1999), microfinance is a provision of a broad range of financial services such as savings, credit, insurance and payment services to the poor or low-income group who are excluded from the normal banking sectors.

The World Bank defines microfinance as “.... Small-scale financial services - primarily credit and savings - provided to people who farm or fish and who operate small enterprises or microenterprises where goods are produced, recycled, repaired, or sold; who provide services; who work for wages or commissions; who gain income from renting out small amounts of land, vehicles, draft animals, or machinery and tools; and to other individuals and groups at the local levels of developing countries, both rural and urban" (Robinson, 2001). However, Bank Negara Malaysia (BNM) defined microfinance as the provision of small loans/financing up to RM50, 000 to microenterprises or self-employed individuals, for their business activities not just for income generating activities. Woller \& Parsons (2002) describe microfinance as the second evolution in credit theory and policy where the first revolution is microcredit. 


\subsection{Microcredit}

Microcredit, also known as micro lending, refers to an extremely small loan, given to impoverished people to help them become self-employed. Microcredit was given to the poor individuals for incomegenerating activities that will improve the borrowers' living standards. The loans characteristics are, too small, short-term credit (a year or less), no collateral, required weekly repayment, poor borrower and mostly women who are not qualified for a conventional bank loan.

Usually the loanee pays high interest rates because of the high cost in running microcredit program. Microcredit is also used as the extension of very small loans to those who are in poverty that designed to spur entrepreneurship and help them out from poverty group. These individuals lack collateral, steady employment and verifiable credit history, which therefore, cannot even meet the most minimal qualifications to gain access to traditional credit. The Grameen Bank defined microcredit as small loans given to the poor for undertaking self-employment projects that would generate income and enable them to provide for themselves and their families. The target population comprising women microenterprises from the low-income households and the loans have no collateral.

\subsection{Group lending performance}

Against the advice of banks and government, Professor Muhammad Yunus a Bangladeshi economist gave out 'micro-loans' to 17 to 42 poor basket weavers from his pocket. He found that it was possible with this tiny amount not only to help them survive, but also to create the spark of personal initiative and enterprise necessary to pull themselves out of poverty and in 1983 he formed the Grameen Bank, meaning 'village bank' founded on principles of trust and solidarity. In Bangladesh today, Grameen has 2,564 branches, with 19,800 staff serving 8.29 million borrowers in 81,367 villages. On any working day Grameen collects an average of $\$ 1.5$ million in weekly installments.

Of the borrowers, $97 \%$ are women and over $97 \%$ of the loans are paid back, a recovery rate higher than any other banking system. Grameen methods are applied in projects in 58 countries, including the US, Canada, France, The Netherlands and Norway. In Thailand, the Bank for Agriculture and Agricultural Cooperative achieved high repayment rates even though it sometimes used groups consisting of as many as 30 members (Huppi and Feder, 1990; Yaron, 1994). Repayment rates are not uniformly high, however for all institutions or across groups within an institution.

In Nepal, the repayment performance of groups formed under the Small Farmers Development Program (SFDP) exhibit a mixed results (Sharma, 1993; Desai and Mellor, 1993) and Bratto(1986) gives examples from Zimbabwe of how group repayment rates can fluctuate according to changing external circumstances. However not all group loans have low default rates. In order to increase loan repayment most of the micro financing schemes in Ethiopia provide loans to organized members, who are not required to put up physical collateral but operate in a group mechanism in which risks of non-repayment are transferred to the group. Essentially, most micro financing schemes in Ethiopia have, with slight modifications, adopted the Grameen Bank micro credit mechanisms (Fantahun, 2000).

Even if group liability claims to improve repayment rates and lower transaction costs when lending to the poor by providing incentives for peers to screen, monitor and enforce each other's loans, the problem of poor loan repayment performance persists. Group financing was introduced in Agricultural finance corporation (AFC) in 2006 with 53 groups in Eldoret Branch being financed approximately 30 million. The recovery rate of the loan was $99.5 \%$ with only two groups defaulting partially. However in the succeeding years, the performance of the group loans has been very erratic. Currently AFC's Eldoret branch has financed 102 groups a sum of Kshs. 64 million with 69 groups being partially or fully in default representing approximately $68 \%$ of the total groups financed. The performing groups were financed a total of Kshs 19 million while those who have a rate of default were financed a total of approximately 45 million part of which has been repaid. This is far below the performance of groups in the preceding studies. This calls for an analysis of factors that may be contributing to this erratic performance of group loans in AFC.

\subsection{Factors Affecting Loan Repayment}

Oladeebo and Oladeebo (2008) examined the determinants of loan repayment among smallholder farmers in Ogbomoso Agricultural Zone, Nigeria. Results from multiple regression analysis showed that amount of loan obtained by farmers, years of farming experience with credit, level of education, were major factors that positively and significantly influenced loan repayment. Many researchers have validated the success of peer monitoring in relation to better repayment performance (Hossain, 1988; Siamwalla et al., 1990; Goetz and Sen Gupta, 1996; Manimekalai, 2004). But, the high frequency of meetings does not necessarily always lead to high level of mutual control (Von, 2004). 
Based on past literature, the factors affecting loan repayment performance of MFIs can be divided into four factors namely individual/borrowers factors, firm factors, loan factors and institutional/lender factors. Several studies (Greenbaum et al., 1991; Hoque, 2000; Colye,2000; Ozdemir \& Boran, 2004) show that when a loan is not repaid, it may be a result of the borrowers' unwillingness and/or inability to repay. Stiglitz and Weiss (1981) recommend that the banks should screen the borrowers and select the "good" borrowers from the "bad" borrowers and monitor the borrowers to make sure that they use the loans for the intended purpose. This is important to make sure the borrowers can pay back their loans.

Greenbaum and Thakor (1995), suggest to look at a borrower's past record and economic prospects to determine whether the borrower is likely to repay or not. Besides characters of the borrowers, collateral requirements, capacity or ability to repay and condition of the market should be considered before giving loans to the borrowers. Some authors link the repayment performance with firm characteristics. Such authors like Nannyonga (2000), Arene (1992) and Oke et al. (2007) mention that firm's profit significantly influenced loan repayment. Besides that, Khandker et al., (1995) raise the question of whether default is random, influenced by erratic behavior, or systematically influenced by area characteristics that determine local productions conditions or branch-level efficiency. Their study on Grameen overdue loans supports the idea of partial influence of area characteristics. Rural electrification, road width, primary educational infrastructure and commercial bank density are positively correlated with a low default rate as well as predicted manager's pay.

Godquin (2004) suggests that the provision of non-financial services such as training, basic literacy and health services has a positive impact on repayment performance. Roslan \& Mohd Zaini (2009) found that borrowers that did not have any training in relation to their business have a higher probability to default. Screening methods are used to screen out bad borrowers. While, Awoke (2004), reports that most of the default arose from poor management procedures, loan diversion and unwillingness to repay loans. Therefore, the lenders must devise various institutional mechanisms that aimed to reduce the risk of loan default.

A few researchers also found that loan characteristics play an important role in determining repayment performance (Roslan \& Mohd Zaini, 2009; Njoku, 1997; Ugbomeh et al., 2008). Copisarow (2000) found that defaults generally arise from poor program design or implementation, not from any essential problems with the borrowers. Roslan Abdul Hakim et al. (2007) in their study conclude that close and informal relationship between MFIs and borrowers may help in monitoring and early detection of problems that may arise in non-repayment of loans. In addition, cooperation and coordination among various agencies that provide additional support to borrowers may help them succeed in their business. The study compared the good practices and performance of selected MFIs in Malaysia namely; Amanah Ikhtiar Malaysia, TEKUN, Koperasi Kredit Rakyat and Bank Pertanian Malaysia.

Koopahi and Bakhshi (2002) used a discriminant analysis to identifying defaulter farmers from nondefaulters of agricultural bank recipients in Iran. Results showed that use of machinery, length of repayment period, bank supervision on the use of loan had significant and positive effect on the agricultural credit repayment performance. In the other hand incidence of natural disasters, higher level of education of the loan recipient and length of waiting time for loan reception had a significant and negative effect on dependent variable.

A research on Factors Affecting on loan Repayment Performance of Farmers in Khorasan-Razavi Province of Iran by Kohansal and Mansoori (2009) showed that farmer's experience, income, received loan size and collateral value have positive effect while loan interest rate, total application costs and number of installment implies a negative effect on repayment performance of recipients. Comparing the elasticities of significant variables indicated that loan interest rate is the most important factor in their model. Farming experience and total application costs are the next factors respectively.

\subsection{Group Loan Repayment Models}

The Grameen Bank (2000a) has identified fourteen different microfinance Models four of which have been discussed below as Agricultural Finance Corporation of Kenya (AFC) has borrowed from them in designing its model.

\subsubsection{Bank Guarantees}

As the name suggests, a bank guarantee is used to obtain a loan from a commercial bank. This guarantee may be arranged externally (through a donor/donation, government agency etc.) or internally (using member savings). Loans obtained may be given directly to an individual, or they may be given to a self-formed group. Bank Guarantee is a form of capital guarantee scheme. Guaranteed funds may be used for various purposes, including loan recovery and insurance claims. Several international and UN organizations have been creating international guarantee funds that banks and NGOs can subscribe to, to lend or start microcredit programs. 


\subsubsection{Grameen}

The Grameen model emerged from the poor-focused grassroots institution, Grameen Bank, started by Prof. Mohammed Yunus in Bangladesh. It essentially adopts a methodology where bank unit is set up with a Field Manager and a number of bank workers, covering an area of about 15 to 22 villages. The manager and workers start by visiting villages to familiarize themselves with the local environment in which they will be operating and identify prospective clientele, as well as explain the purpose, functions, and mode of operation of the bank to the local population. Groups of five prospective borrowers are formed; in the first stage, only two of them are eligible for, and receive, a loan. The group is observed for a month to see if the members are conforming to rules of the bank. Only if the first two borrowers repay the principal plus interest over a period of fifty weeks do other members of the group become eligible themselves for a loan. Because of these restrictions, there is substantial group pressure to keep individual records clear. In this sense, collective responsibility of the group serves as collateral on the loan.

\subsubsection{Group Model}

The Group Model's basic philosophy lies in the fact that shortcomings and weaknesses at the individual level are overcome by the collective responsibility and security afforded by the formation of a group of such individuals. The collective coming together of individual members is used for a number of purposes: educating and awareness building, collective bargaining power, peer pressure etc.

\subsubsection{Peer pressure Model}

Peer pressure model uses moral and other linkages between borrowers and project participants to ensure participation and repayment in microcredit programs. Peers could be other members in a borrowers group (where, unless the initial borrowers in a group repay, the other members do not receive loans. Hence pressure is put on the initial members to repay); community leaders (usually identified, nurtured and trained by external NGOs); NGOs themselves and their field officers; banks etc. The 'pressure' applied can be in the form of frequent visits to the defaulter, community meetings where they are identified and requested to comply etc.

\subsection{Theoretical framework}

\subsubsection{The Grameen Solidarity Group model}

This model is based on group peer pressure whereby loans are made to individuals in groups of four to seven (Berenbach and Guzman, 1994). Group members collectively guarantee loan repayment, and access to subsequent loans is dependent on successful repayment by all group members. Payments are usually made weekly (Ledgerwood, 1999). According to Berenbach and Guzman (1994), solidarity groups have proved effective in deterring defaults as evidenced by loan repayment rates attained by organizations such as the Grameen Bank, who use this type of microfinance model. They also highlight the fact that this model has contributed to broader social benefits because of the mutual trust arrangement at the heart of the group guarantee system. The group itself often becomes the building block to a broader social network.

\subsection{Conceptual framework}

Dependent variable Independent variables

\subsubsection{Independent variables.}

Age of the group is the number of years from the date it was registered with social services department. This was obtained from the groups' registration certificate. Size of the group is the number of members in a group. Years in education represents the total number of years the respondent was in formal education. Size of loan represents the amount of loan granted to the group. It was measured in Kenya Shillings. Experience in loans (Number of loans taken) represents the number of loans taken from Agricultural Finance Corporation. 


\subsubsection{Dependent variables.}

This is the Loan status measured as a percentage of loans in default with those not in default recording zero percent and those whose loan is fully in arrears and have not made partial payment recording $100 \%$.

\subsection{Research design}

\section{Research Methodology}

The research adopted census method to collect data from the sample group members. The census method incorporated all the groups under financing by the state corporation in Uasin Gishu County, Eldoret Kenya

\subsection{Target population}

The target population was group members of 102 group loans in AFC Eldoret Branch in Uasin Gishu County.

\subsection{Sample size and Sampling techniques}

Out of the 102 group loans in AFC Eldoret branch, 69 were partially or fully in default while 33 were not in default. Stratified sampling was used to identify the groups in default and those not in default to be represented in the sample after which simple random sampling was used to select one representative from each group to be represented in the survey 50\% from the default group and 50\% from non-default group.

\subsection{Data collection method}

Primary data was collected by use of structured questionnaire while secondary data was obtained from the groups' AFC branch administrative files.

\subsection{Data analysis and model specification}

The data collected was classified, coded and tabulated in a spread sheet. The data collected was analyzed using descriptive statistical methods which constituted regression analysis. Descriptive methods were used to describe the sample group in terms of averages while multiple linear regressions was used to measure the extent to which the various factors affect the repayment performance of group loans. We estimated a multiple regression equation of the form:

$$
D=\beta_{1}+\beta_{2} A+\beta_{2} L A+\beta_{2} G S+\beta_{2} E X+\beta_{2} E D+\varepsilon
$$

Where: $\mathbf{D}$ is the percentage of loan in default
A is the age of the group
LA is the loan amount
GS is the group size
$\mathbf{E X}$ is the number of times loan has been granted to the group (Experience in loan)
ED is the number of years in formal education
$\varepsilon$ is the stochastic term

IV. Research Findings And Discussions

Table 4.1 Back ground characteristics of the respondents

\begin{tabular}{|l|l|l|l|}
\hline Independent variable & Minimum & maximum & Average \\
\hline Age of group & 3 & 14 & 6.1 \\
\hline Size of group & 15 & 30 & 19 \\
\hline Size of loan & 200,000 & $2,400,000$ & 763,333 \\
\hline Years in education & 4 & 16 & 10.4 \\
\hline Loan experience & 1 & 7 & 6.7 \\
\hline Default status \% & 0 & 100 & 27.9 \\
\hline
\end{tabular}

Table 4.1 above shows in summary, that the minimum group size is 15 which is AFC's policy on group lending. The largest group consists of 30 members. The group with the highest experience is 7 years which means the group has borrowed annually since AFC began its group lending program. The table also shows that the maximum amount of loan financed to a single group in Eldoret branch when the data was collected was KSh 2.4 million and the lowest was KSh 0.2 million. However loans are given based on the group's ability to implement the project and service the loan. 
Analysis of Group Based Loan Default in Kenya: The Case of Agricultural Finance Corporation ....

Table 4.2 Multiple linear regression results

\begin{tabular}{|c|c|c|c|c|}
\hline Mutiple R & 0.532723478 & & & \\
\hline R Squared & 0.283794304 & & & \\
\hline Adjusted $\mathbf{R}^{2}$ & 0.134584784 & & & \\
\hline S.E & 35.42334356 & & & \\
\hline Observations & 30 & & & \\
\hline & Coefficient & S.E & t- stat & $\mathrm{P}-$ value \\
\hline Intercept & 2.492613952 & 53.9226111 & 0.046225765 & 0.963512804 \\
\hline age of group & -1.43574642 & 2.198202668 & -0.65314561 & 0.519870983 \\
\hline size of group & 3.74008474 & 1.915813332 & 1.952217723 & 0.062673102 \\
\hline size of loan & $1.00401 \mathrm{E}-05$ & $1.7107 \mathrm{E}-05$ & 0.586904606 & 0.562748565 \\
\hline Education & -3.1920959 & 2.039305381 & -1.56528587 & 0.130607327 \\
\hline Experience & -2.72473966 & 3.473166247 & -0.78451173 & 0.440415169 \\
\hline
\end{tabular}

From the analysis of the data in Table 4.2, it can be seen that the size of the loan has no effect on loan default. The probability of getting such a result is $56 \%$. Thus, with a t-value of 0.6 less than 2 , confirms that size of the loan has no significant effect on default rate. Further, the group size has a positive effect on default. From the table above it can be observed that a $1 \%$ increase in group size results in $3.740 \%$ increase in default this is statistically significant having a t- value of approximately 2 . The probability of obtaining such a result is however, about $6 \%$. The age of the group, experience and years of education have negative effect on default. For every $1 \%$ change in age of the group there is a reduction of default by $1.436 \%$, with a probability of $52 \%$. Since age can only increase, it means that rate of default reduces as the group age increases. Similarly, for every $1 \%$ change in experience in loan there is a reduction of default by $2.725 \%$ with a probability of $44 \%$. Experience refers to the number of loans taken. The more the number of loans taken, the lesser the risk of default. It can further be observed that for every $1 \%$ increase in years of education there is a reduction of default by approximately $3.192 \%$ which is slightly significant having a t- value of approximately 2 . An $\mathrm{R}^{2}$ value of $28.4 \%$ indicates that age of group, size of loan, size of group, years in education and experience in loan contribute $28.4 \%$ variation in loan default while $71.6 \%$ is caused by factors not in the study.

This low figure of $\mathrm{R}^{2}$ could mean that very important variables could have been omitted from the research model specification. It suggests that, based on these results there is a weak positive relationship between the dependent and the independent variables specified in our model. Note worthy should therefore be the fact that age of the group, group size, experience in loans and education are significant in determining default rate for group loans. Other variables that could be of importance are training in finance and entrepreneurial education, and group supervision by the lending institutions.

\section{Conclusion And Recommendations}

The findings of this study are mixed. Large groups have a high chance of defaulting in loan repayment. This may be attributed to the fact that large groups face serious management challenges and depict high levels of inefficiencies. They may often be characterized by slow decision making and infighting among the members of the group. In this connection, institutions financing groups or following group lending models should consider reducing the membership of the said groups.

It can further be observed that size of the loan does not affect default rate. Providing that the loan amount is pegged on the groups' ability to pay, irrespective of the amount is of no consequence to default rate. Lending institutions should therefore not deny borrowers funds on the basis that the amount involved is too large.

The age of the group is providing an interesting result though. As the age of the group increases, the default rate declines. This could be attributed to the fact that the lending organization could have developed a soft spot for this loyal group or that the group has learnt more relating to the policies on financing such that they are able to take advantage to avoid damaging their image or even that the group could have been trained severally on how to manage and utilize the funds lent. Therefore, while it is important to concentrate on the more mature groups to avoid high rates of default, more focus and attention should be on how to attract more groups to increase the loan portfolio.

The turnover of loans per group is proving very critical. That, providing the group is able to repay its loan within the stipulated contractual guidelines, they should borrow more. These return- borrowers have a reduced default rate as opposed to lending to a totally new group. More emphasis should therefore be placed on second or third time borrowers as the default risk is mitigated. This is because they have amassed a wealth of experience in financial management matters. The educational level of the members comprising the group is also critical. This is corroborated by the fact that the higher the number of years spent schooling or in education, the lower the default rate. This means that for policy purposes, groups should comprise some members who are educated to provide guidance to the other members of the group and decision making. 


\section{Further Research}

Further research should be done to include group supervision, training and other variables which are important but have not been included in this research such as month in which the loan was granted to establish if timely implementation of the project has significant effect on loan repayment. Similar studies can also be undertaken on main stream financial institutions such as banks with group lending models for groups not engaged in farming activities.

\section{References}

[1]. Arene, C.J. (1992). Loan repayment and technical assistance among smallholder maize farmers in Nigeria.

[2]. Awoke, M.U. (2004). Factors affecting loan acquisitioned repayment patterns of smallholder farmers in Inlka North-East of Delta State Nigeria. Journal of Sustainable Tropical Agricultural Research, 9, 61-64.

[3]. Bank Negara Malaysia (BNM). (2007). Bank Negara Malaysia Annual Report 2007. Kuala Lumpur.

[4]. Budiantoro, S. (2004). Financial reform untuk keuangan mikro. CAMEO. Fact about SB 1156: Promoting micro-enterprise. http://www. microbiz.org/html/article_sb1156.htm. Retrieved on 23 June 2008.

[5]. Cotler, P., \& Woodruff, C. (2008). The impact of short term credit on microenterprises: Evidence from the FincomunBimbo program in Mexico. Economic Development and Cultural Change, 830-849.

[6]. Gonzalez-Vega, C. (1998). Microfinance: broader achievements and new challenges. Economics and Sociology Occasional Paper No. 2518. The Ohio State University.

[7]. Greenbaum, S.I., \& Thakor, A.V. (1995). Contemporary financial intermediation. Forth Worth, Texas: Dryden Press.

[8]. Inter- American Development Bank. (1997). Technical guide for the Analysis of Microenterprise Finance Institutions. Microenterprise Division. Washington.

[9]. Kohansal. M. R and Mansoori. H. Factors Affecting on loan Repayment Performance of Farmers in Khorasan-Razavi Province of Iran Tropentag 2009 University of Hamburg, October 6-8, 2009

[10]. Kurwijila, R., \& Due, J.M. (1991). Credit for women's income generation: A Tanzanian case study. Canadian Journal of African Studies, 25(1), 90-103

[11]. Ledgerwood, J. (1999). Microfinance Handbook: An Institutional and Financial Perspective. The World Bank. Washington.

[12]. Ledgerwood J.( 2013) The New Microfnance Handbook: A Financial Market System Perspective International Bank for Reconstruction and Development. The World Bank

[13]. Maata, D. (2004). Examining determinants of group loan repayment in the Dominican Republic. Unpublished Master Dissertation. The Ohio State University. United States.

[14]. Marr, A. (2002). Studying group dynamics: an alternative analytical framework for the study of microfinance impacts on poverty reduction. Journal of International Development, 14(4), 511-534.

[15]. Mel, S.D., McKenzie, D., \& Woodruff, C. (2007). Who does microfinance fail to reach? Experimental evidence on gender and microenterprise returns. http://cpe.ucsd.edu/assets/023/8810.pdf. Retrieved on 5 April 2010.

[16]. Muhammad Yunus (with Alan Jolis). Banker to the Poor: Micro-lending and the battle against world poverty, Public Affairs, NewYork, 1999, pp. 62-63

[17]. Njoku, J. E. (1997). Determinants of loan repayment under the special emergency loan scheme (SEALS) in Niger: A case study in Imo state. African Review of Money Finance and Banking, 1, 39-51.

[18]. Oladeebo, J.O., \& Oladeebo, O.E. (2008). Determinant of loan repayment among smallholder farmers in Ogbomoso Agricultural Zone of Oyo State, Nigeria. Journal of Social Science, 17(1), 59-62.

[19]. Robinson, M. (2002). The Microfinance Revolution: Sustainable Finance for the Poor. The World Bank. Washington, D.C. 38.

[20]. Roslan, A.H., Faudziah, Z.A., Mohd Saifoul, Z.N., \& Rahimah, M. (2007). Microfinance service for micro-enterprise: Good practices and performance of selected microfinance institutions in Malaysia. Journal of Yala Rajabhat University, 2(1), 31-45.

[21]. Schoombee, A. (2000). Getting South African bank to serve micro-entrepreneurs: An analysis of policy options. Development Southern Africa. 17(5). 751- 767.

[22]. Sharma, M., \& Zeller, M. (1997). Repayment performance in group based credit programmes in Bangladesh. World Development, 25(10), 1731-1742.

[23]. Stiglitz, E.J., \& Weiss, A. (1981). Cresit rationing in markets with imperfect information. American Economic Review, 71, 393410 .

[24]. Tambunan, T. (2007). Entrepreneurship development: SMES in Indonesia. Journal of Developmental Entrepreneurship, 12(1), 95-118.

[25]. Woolcock, M.J.V. (1999). Learning from failures in microfinance: what unsuccessful cases tell us about how group-based programs work. American Journal of Economics and Sociology, 58, 17-42.

[26]. Yaron, J. (1994). What makes rural financial markets successful? World Bank Research Observer, 9(1), 49-70. 